\title{
Estimation of the distribution of the total net radiative flux from satellite and automatic weather station data in the Upper Blue Nile basin, Ethiopia
}

\author{
Eyale Bayable Tegegne ${ }^{1,2,3} \cdot$ Yaoming $\mathrm{Ma}^{1,2,4} \mathbb{C} \cdot$ Xuelong Chen ${ }^{1,4} \cdot$ Weiqiang $\mathrm{Ma}^{1,4} \cdot$ Bingbing Wang ${ }^{1} \cdot$ \\ Zhangwei Ding ${ }^{1} \cdot$ Zhikun Zhu $^{1}$
}

Received: 10 February 2020 / Accepted: 16 September 2020 / Published online: 28 October 2020

(C) The Author(s) 2020

\begin{abstract}
Net radiation is an important factor in studies of land-atmosphere processes, water resource management, and global climate change. This is particularly true for the Upper Blue Nile (UBN) basin, where significant parts of the basin are dry and evapotranspiration $(E T)$ is a major mechanism for water loss. However, net radiation has not yet been appropriately parameterized in the basin. In this study, we estimated the instantaneous distribution of the net radiation flux in the basin using data from the Moderate Resolution Imaging Spectroradiometer (MODIS) sensor onboard the Terra satellite and Automatic Weather Station (AWS) data. Downward shortwave radiation and air temperature usually vary with topography, so we applied residual kriging spatial interpolation techniques to convert AWS data for point locations into gridded surface data. Simulated net radiation outputs were validated through comparison with independent field measurements. Validation results show that our method successfully reproduced the downward shortwave, upward shortwave, and net radiation fluxes. Using AWS data and residual kriging spatial interpolation techniques makes our results robust and comparable to previous works that used satellite data at a finer spatial resolution than MODIS. The estimated net shortwave, longwave, and total radiation fluxes were in close agreement with ground truth measurements, with mean bias (MB) values of $-14.84,5.7$, and $20.53 \mathrm{~W} \mathrm{~m}^{-2}$ and root mean square error (RMSE) values $83.43,32.54$, and $78.07 \mathrm{~W} \mathrm{~m}^{-2}$, respectively. The method presented here has potential applications in research focused on energy balance, ET estimation, and weather prediction for regions with similar physiographic features to those of the Nile basin.
\end{abstract}

Yaoming Ma

ymma@itpcas.ac.cn

$\checkmark$ Xuelong Chen

x.chen@itpcas.ac.cn

1 Institute of Tibetan Plateau Research, Chinese Academy of Sciences, 100101 Beijing, People's Republic of China

2 University of Chinese Academy of Sciences, 100864 Beijing, People's Republic of China

3 College of Natural and Computational Sciences, Center for Environmental Science, Addis Ababa University, Addis Ababa, Ethiopia

4 CAS Center for Excellence in Tibetan Plateau Earth Sciences, Chinese Academy of Sciences, 100101 Beijing, People's Republic of China

\section{Introduction}

The net radiation flux is the most important for land surface energy transformations, such as sensible heat, soil heat flux, and evapotranspiration $(E T)$. It is an important quantity for research into land-atmosphere interactions (Blad et al. 1998; Monteith 1965; Niemelä et al. 2001; Nishida et al. 2003; Priestley and Taylor 1972; Rosenberg et al. 1983; Su 2002; Zeng et al. 2015; Zhao et al. 2018), and it is, therefore, important to parameterize net radiation flux appropriately for hydrology and climate modeling studies (Bisht et al. 2005; Ryu et al. 2008). Net radiation is usually measured at specific locations using net radiometers, but it is difficult to generalize from these point measurements to other locations because the net radiation varies spatially and is strongly influenced by the characteristics of the surface over which it is measured, particularly if the surface is highly heterogeneous (Blad et al. 
1998; Chen et al. 2013). Moreover, in many countries, instruments suitable for making direct measurements over a reasonable spatial range are often not available, or are inaccurate, because of technical and financial constraints (Kjærsgaard et al. 2007; Sozzi et al. 1999; Washington et al. 2004).

Alternative methods of estimating net radiation have recently been proposed, using input datasets from radiation modeling and combining field measurements with remote sensing data (Amatya et al. 2015a; Wang et al. 2005). Numerous studies have estimated the instantaneous net radiation flux from data collected by different satellite sensors, including moderate resolution imaging spectroradiometer (MODIS) (Bisht et al. 2005; Cai et al. 2007; Feng and Wang 2017; Hwang et al. 2013; Jia et al. 2013; Peng et al. 2019; Ryu et al. 2008; Slater 2016). However, most of these studies have been limited to flat areas and lack consideration of topography effects. Downward shortwave radiation varies spatially over large and heterogeneous topography, and estimations of radiation that neglect topographic effects can be inaccurate as variations in altitude, slope, orientation (aspect), and shadows cast by topographic features create strong local gradients in solar radiation (Tovar-Pescador et al. 2006; Wang et al. 2005). Many researchers have proposed models that take into account topographic effects (Chen et al. 2013; Dozier 1980; Dubayah 1992; Duguay 1995; Flint and Childs 1987; Gratton et al. 1993; Kumar et al. Pro 1997; Long et al. 2010; Proy et al. 1989) and solar radiation extinction processes (Gueymard 2003a, b; Leckner 1978; Yang et al. 2001; Yang and Koike 2005; Yang et al. 2006) and have used these to estimate net radiation fluxes in mountainous areas. More recently, Chen et al. (2013) have developed a topographically enhanced surface energy balance system (TESEBS) model that combines the effects of topography and solar radiation extinction processes in the atmosphere and have used this to estimate the net radiation flux over the complex topography of Mt. Qomolangma (Everest) areas in China. Amatya et al. (2015a) and Han et al. (2016) have used the TESEBS model to estimate the net radiation flux distribution, and other land surface heat fluxes, on the southern side of the central Himalayas in Nepal and in the Mt. Qomolangma region over the Tibetan Plateau, respectively. The TESEBS model includes atmospheric attenuation and topographic effects while estimating downward shortwave radiation, and so is an important advance for mountainous areas where solar radiation measurements from meteorological stations are totally absent, or are insufficient for reliable spatial interpolation. However, surface radiation calculated by the TESEBS model cannot be as accurate or reliable as direct measurements of radiation made by weather stations distributed evenly over the area of interest.

The Upper Blue Nile (UBN) River in Northwestern Ethiopia is one of the two major tributaries of the Nile River. ET is a major mechanism for surface water loss and accounts over $90 \%$ of the annual precipitation in the dry lowland areas of the river basin (Alemu et al. 2014; Glenn et al. 2007; Kurc and Small 2004; Molden et al. 2007; Morillas et al. 2013; Sun et al. 2019; Wilcox et al. 2003). Even in the wettest parts of the Ethiopian Plateau regions, ET accounts for around $70 \%$ of the basin water balance (NBI 2014). The strength of ET primarily depends on the local energy balance, and most ET estimation methods require the net radiation as an input variable. Hydrologists and water resource managers focused on the UBN basin should therefore implement the latest state-of-the-art methods for estimating the net radiation estimation flux. For this reason, several attempts have been made to estimate ET in the UBN basin, but these have not fully addressed the spatial and temporal variability of the flux, and validation of the calculated ET and net radiation through comparison with ground truth measurements was incomplete in most of the studies (Abreham 2009; Anderson et al. 2011; Enku 2009; Gieske et al. 2008; Mohamed et al. 2005; Senay et al. 2009; Yilmaz et al. 2014).

The main objective of this study is to estimate and characterize the instantaneous net radiation flux distribution in the UBN River basin using Automatic weather stations (AWS) and MODIS data and considering topographic effects. AWS data are recorded and stored automatically and are then transmitted from the stations to a data receiver system via a telemetry system (Ahmad et al. 2017; Sharan 2014; Słownik 1992). Since meteorological data from AWS are recorded and transferred automatically, they are less erroneous than data from conventional stations and have many applications in hydrological studies. The UBN River basin is very important in terms of economic development, and so the Ethiopian government is expanding the AWS network across the basin to enhance the quality of meteorological data available to hydrological studies (Sabatini 2017; Shanko 2015). We hypothesize that the use of AWS data and consideration of topographic effects will result in estimates of net radiation that are more robust than any previous estimates for this part of Africa.

\section{Materials and methods}

\subsection{Study area}

The UBN River basin is located in Northwestern Ethiopia between latitudes $7^{\circ} 40^{\prime}$ and $12^{\circ} 51^{\prime} \mathrm{N}$ and between longitudes $34^{\circ} 25^{\prime}$ and $39^{\circ} 49^{\prime} \mathrm{E}$ (Fig. 1a and b). It drains through large parts of the Central and Southwestern Ethiopian Highlands, the Central Ethiopian Plateau, Lake Tana, and the western arid lowlands of the country. The river has cut a deep and circuitous course. The gorge is $1 \mathrm{~km}$ deep in some places and flows around $900 \mathrm{~km}$ from Lake Tana before leaving Ethiopia and crossing into the vast plains of Sudan (Conway 1997). The basin has a total drainage area of $199,912 \mathrm{~km}^{2}$ (Yilma and Awulachew 2009) and comprises the following two topographically distinct areas: the central and eastern parts of the 


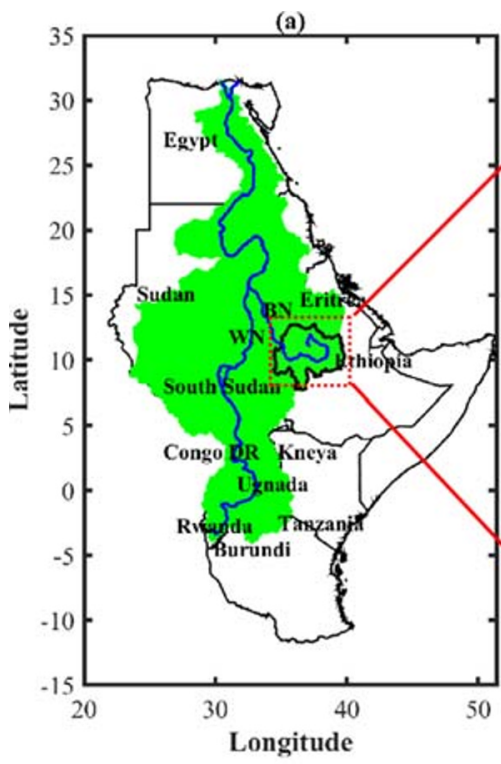

Fig. 1 (a) Location of Nile River Basin with its riparian countries and two major tributaries (WN, White Nile; BN, Blue Nile). Green-shaded portion of the figure is Nile River watershed, the red dashed rectangle is the study area (Upper Blue Nile). (b) Elevation (m) map of the study area

basin are rugged mountainous areas and the western parts are lowlands. Altitude varies significantly across the basin, from below $500 \mathrm{~m}$ above sea level in the lowlands to greater than $4000 \mathrm{~m}$ a.s.l. in the mountains (Fig. 1b).

The climate of the UBN River basin is mainly tropical and is strongly influenced by the movement of air masses associated with the Inter-Tropical Convergence Zone (ITCZ) (Conway 2000; Mohamed et al. 2005). During the months of November to March, dry continental air masses flow over the Ethiopian Highlands from the Northeast. From March to May, the ITCZ brings a small amount of rainfall, known locally as "Belg," to the northeastern part of the basin, while the rest part of the basin is dry. From June to October, the southwestern air stream extends over the entire basin, bringing the rainy season. Both temperature and precipitation vary significantly with altitude in the basin. Lowland areas are warmer and drier than highland areas (Abtew et al. 2009; Conway 2005; Zeleke et al. 2013), and the mean maximum and minimum temperatures both vary seasonally, although the range is not as great as in the high latitude regions.

Land cover also varies in the UBN River basin. Woodland and shrub cover large parts of the basin $(\sim 28 \%)$, followed by sedentary rain-fed cropping, which covers nearly $26 \%$ of the basin, mainly in the highlands areas, and includes different crop types, such as Eragrosist (Teff), barley, and wheat. Grasslands cover around $25 \%$ of the basin and are concentrated along the main river course and tributary rivers, and shrubs and bushes cover the remaining $21 \%$. This latter land cover type is mainly located along the river gorges and in the vast western parts of the basin (ENTRO 2007; Lemann et al. 2019; Medhin 2011; Roth et al. 2018). (b)

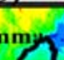


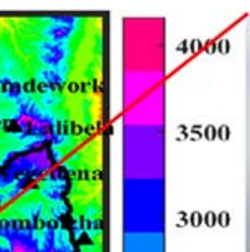

$(c)$

(c)
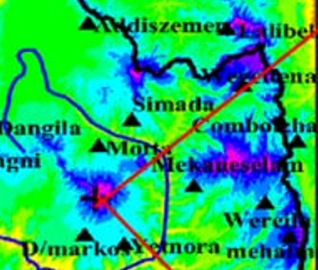

Gimarkos Ashambu

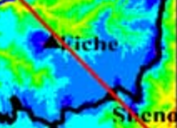

$12 \hat{3}$ Adatis Ababat $\Delta$ Wolise Jimme 37E 38E 39E

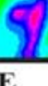

Longitude

delineated by the black-lined shape file, automatic weather station (AWS) distributions (black up-pointing triangle), and location of eddy covariance (EC) tower $(+)$; (c) picture of installed EC instrument and its surrounding area

\subsection{Input datasets}

\subsubsection{Meteorological forcing data}

We used in situ meteorological AWS data (air temperature, global radiation, and relative humidity) from the National Meteorological Agency database for Ethiopia (Shanko 2015). Data measured at $2 \mathrm{~m}$ height were selected for times coincident with satellite overpass times. We chose to use AWS data because they provide a continuous times series and so can be matched to instantaneous remote sensing measurements.

Surface pressure is usually recorded at meteorological stations and is important for estimating net radiation (Yang et al. 2006); however, surface pressure data were not included in our AWS datasets and so instead it is estimated from the relationship between sea level pressure $\left(\mathrm{p}_{0}\right)$ and elevation. As elevation in our study area varies from $420 \mathrm{~m}$ to higher than $4200 \mathrm{~m}$ (Fig. 1b), the estimated surface pressure also varies significantly. The surface pressure is estimated from $p_{\mathrm{s}}=p_{0} \exp (-\mathrm{Z} / \mathrm{H})$, following Chen et al. (2013) and others, where $p_{0}=101,325 \mathrm{~Pa}$, and $\mathrm{H}=8430 \mathrm{~m}$ is scale height, and $\mathrm{Z}$ is altitude (in $\mathrm{m}$ ), read for each location from a digital elevation model (DEM) of the study area. Data were initially taken from 56 AWSs located in the basin and its immediate vicinity, but after vigorous quality control checks for internal consistency and technical sensor problems, based on procedures in Estévez et al. (2011) and WMO (2007, 2017), stations with spurious data and inaccurate measurements were excluded and data from 43 stations were retained for our study. To convert meteorological station data into surface 
data, appropriate spatial interpolation techniques were implemented for each data type as briefly discussed in Section 2.

\subsubsection{Remote sensing data}

MODIS multispectral sensors on board the National Aerodynamic and Space Administration's (NASA) Earth Observation System (EOS) Terra and Aqua satellites have continuously monitored the Earth's land, atmosphere, and ocean since December 1999 and May 2002, respectively (Amatya et al. 2015b). In this study, we used MODIS products from the Terra satellite as an input to the TESEBS model. MODIS observations are recorded in 36 wide spectral bands that cover the solar reflectivity and thermal emissivity regions of the spectrum (Xiong et al. 2009). These data have been used to improve our understanding of global dynamics and of processes occurring on land, in the oceans, and in the lower atmosphere (Masuoka et al. 1998; Rosenberg et al. 1983). MODIS data provide a consistent and wide range of simultaneous measurements for the land surface, biosphere, and atmosphere, including skin temperature, land cover, and the normalized difference vegetation index (NDVI) (Jin and Dickinson 2010; Jin and Mullens 2012). Analyzing these variables is useful for research into land surface-biosphere-atmosphere interactions, such as the work presented here. We used surface reflectance from bands 1 to 7 at a spatial resolution of $500 \mathrm{~m}$ from the land product MOD09GA. Land surface temperature (LST) with a spatial resolution of $1 \mathrm{~km}$ was taken from the land product MOD11A1 (Table 1). The surface reflectance data were resampled to $1 \mathrm{~km}$ resolution for consistency with the $L S T$ data so that both datasets could be used as model inputs. We selected cloud-free MODIS scenes over the study area; however, MODIS data are strongly susceptible to cloud contamination over tropical Africa (Hansen et al. 2008; Roy et al. 2006). This study was carried out during the precipitous period that precedes the main rainy season, when boundary layer atmospheric processes may enhance local cloud formations over the south and southwestern parts of the study area. This meant that cloud-free Terra satellite scenes were only available for 11 dates (Table 2). Land surface parameters, such as albedo, emissivity, fractional vegetation cover, and NDVI, were calculated using the equations presented in Section 2.
Table 2. MODIS data dates with their respective acquisition local times (year, 2019).

\begin{tabular}{llll}
\hline Sr. no. & Month & Date & Satellite pass time \\
\hline 1 & 2 & 10 & $11: 12 \mathrm{am}$ \\
2 & 2 & 18 & $10: 24 \mathrm{am}$ \\
3 & 2 & 26 & $11: 12 \mathrm{am}$ \\
4 & 2 & 27 & $10: 18 \mathrm{am}$ \\
5 & 3 & 2 & $10: 48 \mathrm{am}$ \\
6 & 3 & 20 & $10: 36 \mathrm{am}$ \\
7 & 3 & 25 & $10: 54 \mathrm{am}$ \\
8 & 3 & 26 & $10: 00 \mathrm{am}$ \\
8 & 4 & 1 & $11: 00 \mathrm{am}$ \\
10 & 4 & 25 & $10: 12 \mathrm{am}$ \\
11 & 5 & 14 & $10: 06 \mathrm{am}$ \\
\hline
\end{tabular}

\subsubsection{Digital elevation model}

Shuttle Radar Topography Mission (SRTM) digital elevation model (DEM) data with a spatial resolution of 1 arc-second were obtained from the United States Geological Survey (USGS) website (http://earthexplorer.usgs.gov/). This dataset has a spatial resolution of $30 \mathrm{~m}$ and was resampled to $1 \mathrm{~km}$ grid. The coordinate system and map projection used for the DEM are WGS-1984-UTM-Zone 37N. The DEM allows us to include the effects of topography (elevation, slope, and aspect) in our estimates of the spatial distributions for air temperature and for the downward shortwave radiative flux.

\subsection{Theory and scheme}

The net radiation flux is the algebraic sum of all radiative energy fluxes that leave, or are incident upon, a given surface. In this study, we used equations from the TESEBS model to parameterize the upward shortwave, upward longwave, and downward longwave components of the net radiation flux. The downward shortwave component of the flux, $S W d$, was read from the spatially interpolated AWS data. For a detailed description of the parameterizations in the TESEBS model, we refer the reader to Chen et al. (2013) and Han et al. (2016). In this work, we used only the equations needed to parameterize the stated fluxes. The net radiation flux can be estimated at various spatial scales using different approaches. Detailed ground observations or high-resolution satellite data,
Table 1. MODIS products used in this study

\begin{tabular}{lllll}
\hline Product name & Product types & Parameter used & Temporal resolution & Spatial resolution \\
\hline MOD09GA & Surface reflectance & Bands 1,2,3,4,5, and 7 & 1 day & $500 \mathrm{~m}$ \\
MOD11A1 & Land products & LST & 1 day & $1 \mathrm{~km}$ \\
\hline
\end{tabular}


for example, from Landsat (e.g. Chen et al. 2013), can be used to estimate the net radiation flux at the micro- and mesoscales. Our aim was to estimate the regional net radiation flux at a basin level, using the MODIS data products and AWS data as described subsequently.

The net radiation flux $\left(R_{n}\right)$ can be obtained from Eq. (1)

$R_{\mathrm{n}}(\mathrm{x}, \mathrm{y})=S W d(\mathrm{x}, \mathrm{y})-S W u(\mathrm{x}, \mathrm{y})+L W d(\mathrm{x}, \mathrm{y})-L W u(\mathrm{x}, \mathrm{y})$ $R_{n}(\mathrm{x}, \mathrm{y})=\left(1-\mathrm{r}_{0}(\mathrm{x}, \mathrm{y})\right) S W d(\mathrm{x}, \mathrm{y})+L W d(\mathrm{x}, \mathrm{y})-\delta \varepsilon_{0}(\mathrm{x}, \mathrm{y}) L S T$

where $S W d$ and $S W u$ are the incoming and outgoing shortwave radiation fluxes and $L W d$ and $L W u$ are the incoming and outgoing longwave radiation fluxes, respectively. $r_{0}$ is the surface albedo, calculated from the narrow band spectral value (e.g. Liang 2001); $L S T$ is the surface temperature $(\mathrm{K})$ that may be derived differently to the method used to retrieve it from the satellite data; $\varepsilon_{0}$ is the surface emissivity, which can be estimated from NDVI or from the fractional vegetation cover using the model described in Valor and Caselles (1996); and $\delta$ is the Stefan-Boltzmann constant $\left(=5.676 \times 10^{-8} \mathrm{~W} \mathrm{~m}^{-2} \mathrm{k}^{4}\right)$.

Over homogeneous terrain, surface meteorological variables can be easily estimated from point weather station data, using either inverse distance or ordinary kriging interpolation techniques. However, these techniques provide less reliable estimates over more complex topography and/or more heterogeneous land surfaces (Alsamamra et al. 2009; Daly et al. 2002; Marquínez et al. 2003). The topography in the UBN
River basin is rugged and varies considerably in altitude (Melesse et al. 2014; Jury 2011). Variations in the topography (elevation, slope, and aspect) can influence the accuracy of interpolated surface meteorological variables when either inverse distance or ordinary kriging methods are applied. To overcome this, there is a need for new procedures to be proposed that include topographical information in the interpolation procedure ${ }_{4}$ Various studies state that the residual kriging (RK) proce(Xure is the easiest and most appropriate technique (e.g., Eldeiry and Garcia 2009; Prudhomme and Reed 1999). RK is a spatial interpolation technique that combines regression of the dependent variable on the explanatory variables (in this case, elevation, aspect, and slope) with kriging for the regression residuals (Pebesma 2006). As solar radiation and air temperature vary across heterogeneous terrain, we use RK when we convert the AWS solar radiation and air temperature point location data to spatially distributed surface data. Details of the procedures we followed for this are discussed in Sections 2.3.1 and 2.3.2. An overview of the general concepts governing our method for estimating the net radiation flux is presented in Fig. 2.

\subsubsection{Air temperature $\left(T_{\text {air }}\right)$ and vapor pressure $\left(e_{\mathrm{a}}\right)$}

Air temperature was taken from a limited number of AWSs, and so the data represent the temperature at specific point locations and may not be representative of the wider study area (Li and Heap 2011; Ninyerola et al. 2000). We therefore
Fig. 2 Flow chart showing the details of data processing and net radiation flux estimation procedures

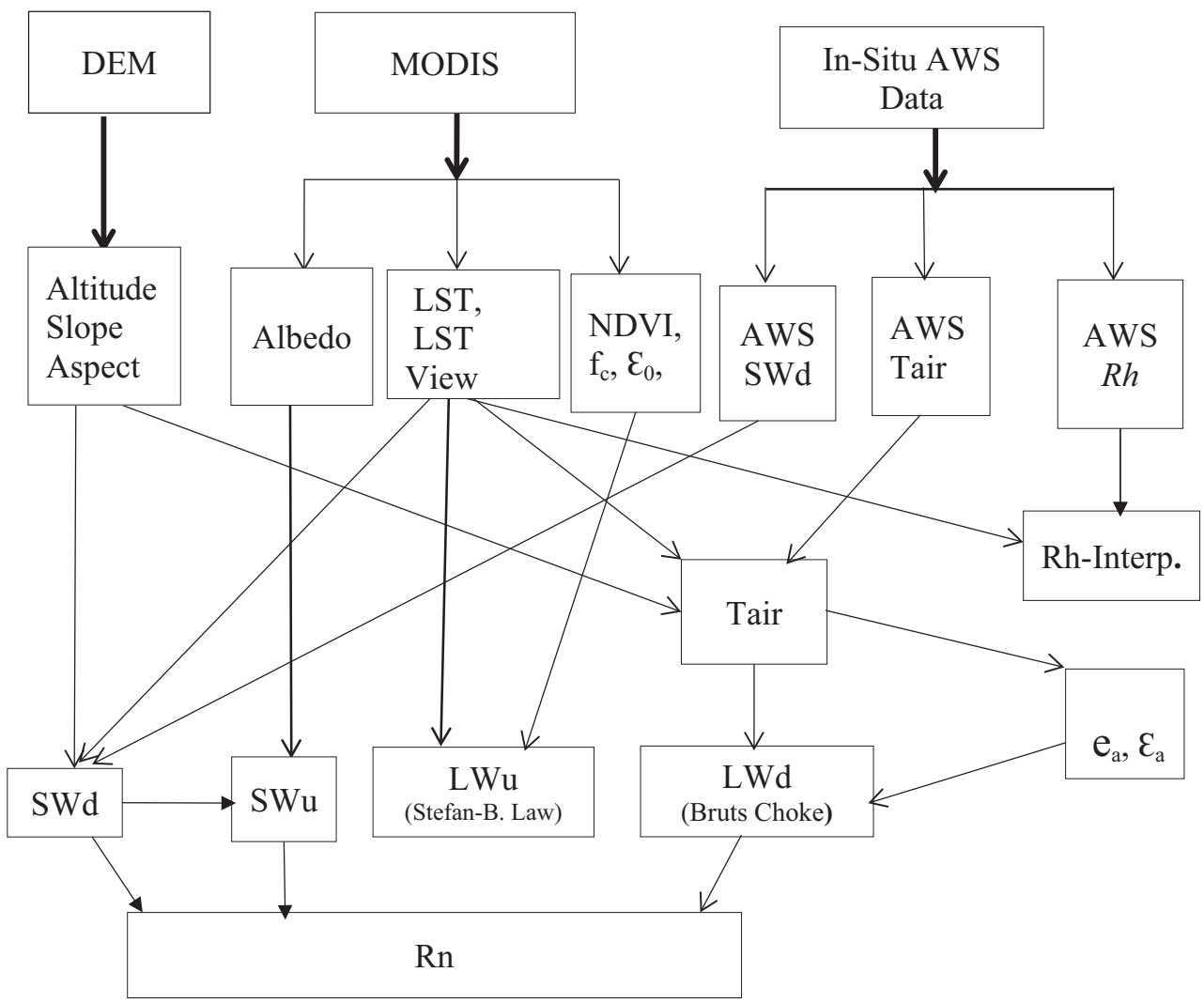


interpolated our air temperature dataset from point-scale measurements to the regional scale using appropriate methods (Liu et al. 2016). Our study area is mountainous and air temperature changes with elevation, so we implemented an interpolation that considers the effects of elevation on air temperature (Dodson and Marks 1997). Since $L S T$ largely controls the air temperature spatial distribution, it is also possible to obtain air temperature at regional scales from $L S T$, as has been demonstrated in various studies (Colombi et al. 2007; Flores and Lillo 2010; Gallo et al. 2011; Hachem et al. 2012; Hadria et al. 2018; Shen and Leptoukh 2011; Sun et al. 2005; Vancutsem et al. 2010; Tadesse et al. 2015). We postulated that using both $L S T$ and elevation to estimate air temperature would increase the accuracy of the estimated air temperature spatial distribution. We applied residual kriging (RK) to estimate the surface air temperature from $L S T$ and elevation following the process described subsequently:

1. Let the AWS air temperature be denoted by $T_{\text {air }}(\mathrm{x}, \mathrm{y})$, where $(\mathrm{x}, \mathrm{y})$ is the position of each AW station. The elevation and $L S T$ for each AWS location were extracted from the DEM and from the MODIS $L S T$, respectively. The extracted point values were treated as explanatory variables, and robust fitting was carried out between $T_{\text {air }}(\mathrm{x}, \mathrm{y})$, elevation, and $L S T$ using Eqs. (2a) and (2b).

$$
\begin{aligned}
T_{\text {air }}(\mathrm{x}, \mathrm{y})= & T_{\text {air }}{ }^{*}(\mathrm{x}, \mathrm{y})+\mathrm{r}(\mathrm{x}, \mathrm{y}) \\
= & \sum\left(\beta_{\mathrm{i}} \mathrm{a}_{\mathrm{i}}(\mathrm{x}, \mathrm{y})\right)+\mathrm{r}(\mathrm{x}, \mathrm{y}) \\
T_{\text {air }}(\mathrm{x}, \mathrm{y})= & \beta_{0}+\beta_{1} \text { elevation }(\mathrm{x}, \mathrm{y})+\beta_{2} L S T(\mathrm{x}, \mathrm{y}) \\
& +r(\mathrm{x}, \mathrm{y})
\end{aligned}
$$

where $\beta_{i}=\beta_{0}, \beta_{1}$, and $\beta_{2}$ are the constant and coefficients for the robust regression; $\mathrm{a}_{\mathrm{i}}(\mathrm{x}, \mathrm{y})$ is the elevation and $L S T$ at an AWS location; and $r(\mathrm{x}, \mathrm{y})$ is the residual error. $T_{\text {air }}{ }^{*}(\mathrm{x}, \mathrm{y})$ is the deterministic (regressed) part of the model. The residual error, $r(\mathrm{x}, \mathrm{y})$, is the difference between the AWS value for $T_{\text {air }}(\mathrm{x}, \mathrm{y})$ and the regressed value $T_{\text {air }}{ }^{*}(\mathrm{x}, \mathrm{y})$ used in Eq. (2a):

$r(\mathrm{x}, \mathrm{y})=\operatorname{Tair}(\mathrm{x}, \mathrm{y})-T_{\text {air }}{ }^{*}(\mathrm{x}, \mathrm{y})$

2. We apply the regression model to all points on a grid covering the study area (except the AWS locations). Some parts of $T_{\text {air }}$ can be estimated at all grid points using the regression part of Eq. (2b), the gridded elevation values (DEM), and LST:

$\mathrm{T}_{\text {grids }}^{*}=\beta_{0}+\beta_{1} \mathrm{DEM}+\beta_{2} \mathrm{LST}$
Where $T^{*}$ grids is the gridded $T_{\text {air }}$, with a spatial resolution equal to that of the grids for $L S T$ and DEM, DEM are the gridded elevation values, and $L S T$ is the gridded land surface temperature.

3. A separate kriging procedure was applied to the residual, $r(\mathrm{x}, \mathrm{y})$. Finally, a map of $\widehat{\mathrm{T}}_{\text {grids }}$ was obtained by combining $T_{\text {grids }}^{*}$ and $\widehat{r}_{\text {grid }} S$ as:

$\widehat{\mathrm{T}}_{\text {grids }}=\mathrm{T}_{\text {grids }}^{*}+\widehat{\mathrm{r}}_{\text {grids }}$

where $\mathrm{T}_{\text {grids }}$ is the estimated air temperature and $\mathrm{T}^{*}$ grids and $\widehat{\mathrm{r}}_{\text {grids }}$ are the trend and residual part of the regression, respectively, at the grid spatial scale.

Atmospheric water vapor is recorded in the AWS data as relative humidity $(R h)$, which we interpolated spatially to obtain values on the same surface grid as for the other variables.

Relative humidity has nonlinear function with topographic variables (Liston and Elder 2006), and its spatial distribution is largely constant over areas which are a long way from major water sources, such as our study area (Beek 1991). This makes ordinary kriging an appropriate method for spatial interpolation, and we applied it in here. The spatially interpolated relative humidity ( $R h$-interp) was then converted to vapor pressure $\left(e_{a}\right)$ using the standard conversion methods for saturated vapor pressure (WMO C 2008) found in the TESEBS model. The spatially interpolated $T_{\text {air }}$ and $\mathrm{e}_{\mathrm{a}}$ were validated using 32 (74\%) of the AWS datasets as a training dataset, and the other $11(26 \%)$ independent, randomly selected AWS datasets as a test dataset (Fig. 3a and b). Though the biases and RMSE were small for $T_{\text {air }}$ and $e_{i}$, these statistical metrics were relatively large for the downward longwave radiation flux that was calculated from them (Fig. 3c). This was due to the sensitivity of downward longwave radiation calculation to both air temperature and water vapor pressures.

\subsubsection{Downward shortwave radiation (SWd)}

Shortwave radiation comprises about $85 \%$ of the incident solar radiation flux (Sardar et al. 2017), and it is the largest term in the surface energy balance (Cuffey and Paterson 2010). $S W d$ varies both spatially and temporally over the Earth's surface. Terrain characteristics (elevation, slope, and orientation of terrain features/aspects) drive variability in $S W d$ at the surface in mountainous areas (Olson et al. 2019). Elevated surfaces have a lower atmospheric thickness than lower lying land surfaces, and the $S W d$ incident on these surfaces has therefore been subject to lower atmospheric attenuation. The increase in $S W d$ with elevation makes elevation an important explanatory variable for regression-based interpolation 
(a) Tair

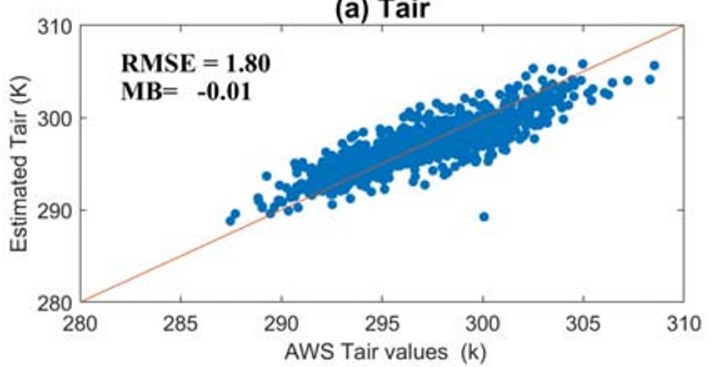

(c) LWd

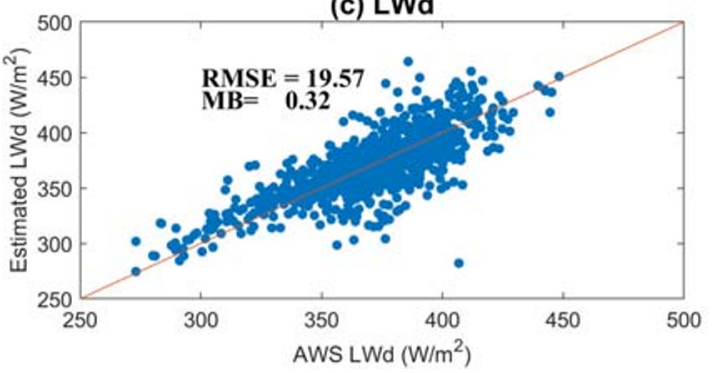

(b) ea

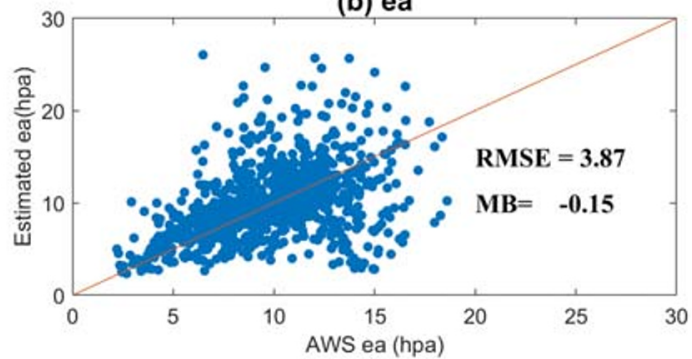

(d) SWd

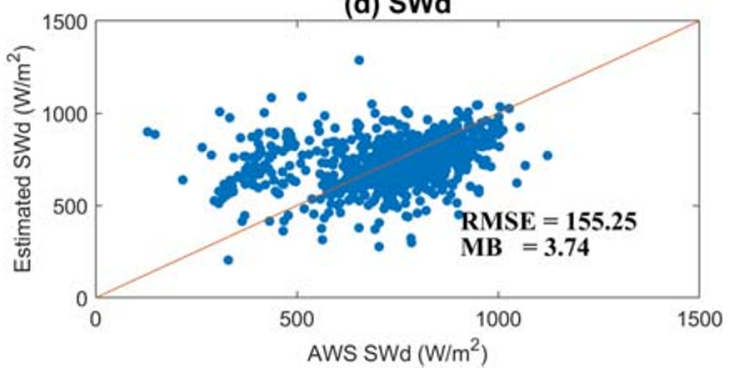

Fig. 3 Graphs of cross-validation results: (a) air temperature (Kelvin), (b) vapor pressure (hPa), (c) downward longwave radiation (W $\left.\mathrm{m}^{-2}\right)$, and (d) downward shortwave radiation $\left(\mathrm{W} \mathrm{m}^{-2}\right)$

(Alsamamra et al. 2009; Martínez-Durbán et al. 2009). The distribution of incident solar radiation is also influenced by both slope and aspect in mountainous areas. In the Northern Hemisphere, south-facing slopes and ridges receive high levels of $S W d$, while canyon bottoms and north-facing slopes receive less (Rich et al. 1995; Charabi and Gastli 2010; Li 2013). Moreover, depending on the solar zenith angle, areas with steep slopes can block direct solar radiation that would otherwise reach opposing sun-facing slopes. Interpolation over areas of rugged terrain should therefore take terrain characteristics into account.

Estimates of $S W d$ over large spatial areas are needed in the fields of agriculture, renewable energy, and hydrological studies and can be obtained through interpolation of meteorological station data. In mountainous areas, $S W d$ varies with altitude, surface gradient, and orientation (Dozier 1980; Dubayah 1992; Duguay 1995; Flint and Childs 1987), making RK the most appropriate interpolation method because it accounts for topography (Alsamamra et al. 2009; Dobesch et al. 2013; Dyras and Ustrnul 2007; Hengl 2009; Holdaway 1996; Liao and Li 2004; Prudhomme and Reed 1999; Sluiter 2009; Wu and Li 2013).

The UBN River basin is characterized by highly rugged topography and a considerable range of altitudes (Melesse et al. 2014; Jury 2011). The ruggedness of the basin topography suggests that both steepness and slope orientation are highly variable (Mukherjee et al. 2013). The incident solar radiation is strongly influenced by variations in elevation, slope, and aspect across the region (Hoch and Whiteman 2010; Vico and Porporato 2009). Any spatial interpolation of $S W d$ in the UBN River basin should therefore account for the effects of elevation, slope, and aspect, for example by using RK techniques. We used this method to interpolate $S W d$ values from the AWS data as follows:

1. Let AWS global radiation be denoted by $S(\mathrm{x}, \mathrm{y})$, where (x, $\mathrm{y})$ is the location of each AWS station. The environmental variables, elevation, slope, and aspect, were read from the DEM for each AWS location, and a robust liner regression was implemented. Robust fitting was carried out for $S(\mathrm{x}, \mathrm{y})$ and the extracted variables using Eqs. (6a) and (6b).

$$
\begin{aligned}
S(\mathrm{x}, \mathrm{y})= & S^{*}(\mathrm{x}, \mathrm{y})+r(\mathrm{x}, \mathrm{y})=\sum\left(\beta_{\mathrm{i}} \mathrm{a}_{\mathrm{i}}(\mathrm{x}, \mathrm{y})\right)+r(\mathrm{x}, \mathrm{y}) \\
\mathrm{S}(\mathrm{x}, \mathrm{y})= & \beta_{0}+\beta_{1} \text { elevation }+\beta_{2} \text { slope } \\
& +\beta_{3} \operatorname{aspect}(\mathrm{x}, \mathrm{y})+\mathrm{r}(\mathrm{x}, \mathrm{y})
\end{aligned}
$$

Where $\beta_{0}, \beta_{1}, \beta_{2}$ and $\beta_{3}$ are the constant and coefficients for the robust regression; $\mathrm{a}_{\mathrm{i}}(\mathrm{x}, \mathrm{y})$ are the values of environmental variables at each AWS location; $r(\mathrm{x}, \mathrm{y})$ is the residual error; and $S^{*}(\mathrm{x}, \mathrm{y})$ is the deterministic (regressed) part of the model.

2. The residual error, $r(\mathrm{x}, \mathrm{y})$, is the difference between the AWS values for $S(\mathrm{x}, \mathrm{y})$ and the regressed value $S^{*}(\mathrm{x}, \mathrm{y})$ from Eq. (6):

$r(\mathrm{x}, \mathrm{y})=S(\mathrm{x}, \mathrm{y})-S^{*}(\mathrm{x}, \mathrm{y})$ 
3. The regression model is implemented for all points in a grid covering the study area (except the AWS locations). Some parts of $S W d$ can be estimated at all grid points using the regression part of Eq. (6b).

$$
\begin{aligned}
S^{*}(\text { grids })= & \beta_{0}+\beta_{1} \text { Elevation }(\text { grids })+\beta_{2} \text { Slope }(\text { grid }) \\
& +\beta_{3} \text { Aspect }(\text { grids })
\end{aligned}
$$

where Elevation, Slope, and Aspect are the gridded values of elevation, slope, and aspect, respectively.

4. A separate kriging procedure was implemented for the residual part, $\mathrm{r}(\mathrm{x}, \mathrm{y})$, which was then converted to $\widehat{r}$ (grids). Finally, a map of $\widehat{S}$ (grids) was obtained by combining $S^{*}($ grids $)$ and $\widehat{r}$ (grids):

$\widehat{S}($ grids $)=S^{*}($ grids $)+\widehat{r}($ grids $)$

where $S_{\text {grids }}^{*}$ is the regressed model output for all grid points except the AWS locations; $r^{*}$ grids is spatially interpolated residual; and $\widehat{S}_{\text {grids }}$ is the total downward solar radiation at the spatial scale of the grid. These results were validated as for $T_{\text {air }}$ and $e_{\mathrm{a}}$, and the result (Fig. 3d) shows that the RK spatial interpolation technique is promising for estimating $S W d$ with a relatively small MB and RMSE.

\subsubsection{Upward shortwave radiation $(S W u)$}

The $S W u$ flux is solar radiation that is reflected back to space from the land surface. The ratio of $S W u$ to the total incident solar radiation is the planetary albedo $\left(r_{0}\right)$, which is a property of the land surface (Stephens et al. 2015). $S W u$ can therefore be estimated from the downward solar radiation and the surface albedo:

$S W u=r_{0} S W d$

The surface albedo $\left(r_{0}\right)$ was calculated from MODIS narrow spectral reflectance bands using a linear combination equation from Liang (2001):

$$
\begin{aligned}
\mathrm{r}_{0}= & 0.160 \alpha_{1}+0.291 \alpha_{2}+0.243 \alpha_{3}+0.116 \alpha_{4} \\
& +0.112 \alpha_{5}+0.081 \alpha_{7}-0.0015
\end{aligned}
$$

where ${ }_{1} \rightarrow$ are the reflectivity values for MODIS bands $1-$ 7 , respectively.

\subsubsection{Downward longwave radiation $(L W d)$}

The $L W d$ flux is radiation emitted from aerosols, water vapor, and other gaseous molecules and depends mainly on temperature and water vapor concentration in the lower atmosphere (Schmetz 1989; Wang and Dickinson 2013). It is an important component of the energy flux across the land-atmosphere interface, and its absence would result in mean global surface temperature being 30 to $40{ }^{\circ} \mathrm{C}$ cooler than it is (Sellers 1965; Trigo et al. 2010). The method used most frequently to parameterize $L W d$ is from Brutsaert (1975), expressed in its original form in Eq. (12) (Amatya et al. 2016; Chen et al. 2013; Han et al. 2013; Kjærsgaard et al. 2007; Long et al. 2010). We recalibrated this original method to be more appropriate to our study area, as is described in more detail in Section 3.

$L W d=\varepsilon_{\mathrm{a}} \delta T_{a i r}{ }^{4}$

Where $\delta$ is the Stefan-Boltzmann constant $\left(=5.67 \times 10^{-8}\right.$ $\mathrm{W} \mathrm{m} \mathrm{m}^{-2} \mathrm{~K}^{-4}$ ), $T_{\text {air }}$ (in $\mathrm{K}$ ) is the near surface air temperature, $e_{a}$ (in $\mathrm{hPa}$ ) is the actual vapor pressure, and $\varepsilon_{\mathrm{a}}$ is the clear sky air emissivity, obtained using an empirical formula:

$\varepsilon_{\mathrm{a}}=1.24\left(\frac{\mathrm{e}_{\mathrm{a}}}{T_{\text {air }}}\right)^{1 / 7}$

\subsubsection{Upward longwave radiation $(L W u)$}

The Earth absorbs shortwave radiation from the sun, after it has passed through the atmosphere and radiates at an equilibrium temperature that is close to the surface temperature. This process is described by the Stefan-Boltzmann law, which we used to parameterize the $L W u$ flux:

$L W u=\varepsilon_{0} \delta L S T^{4}$

Where $\delta$ is Stefan Boltzmann constant; $L S T$ is the land surface temperature from the MOD11A1 product; and $\varepsilon_{o}$ is the surface emissivity. The surface emissivity $\varepsilon_{0}$ was calculated following Valor and Caselles (1996):

$\varepsilon_{\mathrm{o}}=\varepsilon_{\mathrm{v}} \mathrm{f}_{\mathrm{c}}+\varepsilon_{\mathrm{g}}\left(1-\mathrm{f}_{\mathrm{c}}\right)+\langle\mathrm{d} \varepsilon\rangle\left(1-\mathrm{f}_{\mathrm{c}}\right)$

where $\varepsilon_{v}=0.985( \pm 0.007)$ is the surface emissivity for full vegetation cover; $\varepsilon_{g}=0.96( \pm 0.010)$ is the surface emissivity of the bare soil; $\langle\mathrm{d} \varepsilon\rangle=0.015( \pm 0.008)$ is the error; and $f_{c}$ is the fractional vegetation coverage, estimated following Carlson and Ripley (1997):

$f_{c}=\left(\frac{N D V I-N D V I_{\min }}{N D V I_{\max }-N D V I_{\min }}\right)^{2}$

where $N D V I_{\max }=0.8$ and $N D V I_{\min }=0.2$ are the $N D V I$ values 
Table 3. Comparisons of validation results among Brutsaert (1975) and BrutsaertChoke methods

\begin{tabular}{|c|c|c|c|c|c|c|c|}
\hline \multirow{2}{*}{$\begin{array}{l}\text { Sr. } \\
\text { no. }\end{array}$} & \multirow{2}{*}{$\begin{array}{l}\text { Radiation } \\
\text { variables }\end{array}$} & \multicolumn{2}{|c|}{ Brutsaert (1975) } & \multicolumn{2}{|c|}{ Bruts-Choke method } & \multicolumn{2}{|c|}{$\%$ of error reduction } \\
\hline & & $\begin{array}{l}\text { RMSE (W } \\
m^{-2} \text { ) }\end{array}$ & $\begin{array}{l}\text { MB (W } \\
\left.m^{-2}\right)\end{array}$ & $\begin{array}{l}\text { RMSE (W } \\
m^{-2} \text { ) }\end{array}$ & $\begin{array}{l}\mathrm{MB}(\mathrm{W} \\
\left.\mathrm{m}^{-2}\right)\end{array}$ & $\begin{array}{l}\text { RMSE (W } \\
m^{-2} \text { ) }\end{array}$ & $\begin{array}{l}\mathrm{MB}(\mathrm{W} \\
\left.\mathrm{m}^{-2}\right)\end{array}$ \\
\hline 1 & LWd & 32.42 & -27.82 & 18.35 & 5.61 & 43.40 & 79.83 \\
\hline 2 & LW-net & 35.26 & -16.36 & 32.73 & 5.82 & 7.18 & 135.57 \\
\hline 3 & $R_{\mathrm{n}}$ & 115.37 & -65.98 & 94.94 & -15.55 & 11.71 & 76.43 \\
\hline
\end{tabular}

for full vegetation and bare soil, respectively (Gandhi et al. 2015).

$\mathrm{MB}=\sum_{\mathrm{i}=1}^{\mathrm{n}}\left(\mathrm{x}_{\mathrm{i}}-\mathrm{obs}_{\mathrm{i}}\right)$

$\mathrm{RMSE}=\sqrt{\frac{\sum_{\mathrm{i}=1}^{\mathrm{n}} \mathrm{x}_{\mathrm{i}}-\mathrm{obs}_{\mathrm{i}}}{\mathrm{N}}}$

\section{Results and discussion}

\subsection{Validation}

In surface energy balance studies, mean bias $(\mathrm{MB})$ and root mean square error (RMSE) are the statistical tools most commonly used for validation. In this work, in situ measurements of eddy covariance radiation fluxes were averaged over 30 min intervals, and the model data were compared with the in situ radiation flux for the same time, allowing MB and RMSE to be found:

where $x_{\mathrm{i}}$ is the model value, $o b s_{\mathrm{i}}$ is the observed (measured) value for the same time, and $N$ is number of sample observations.

\subsection{Calibration for downward longwave radiation (LWd)}

Despite much research into $L W d$ estimation methods for the lower atmosphere, an accurate, universally appropriate method has not yet been found. There is growing interest in finding
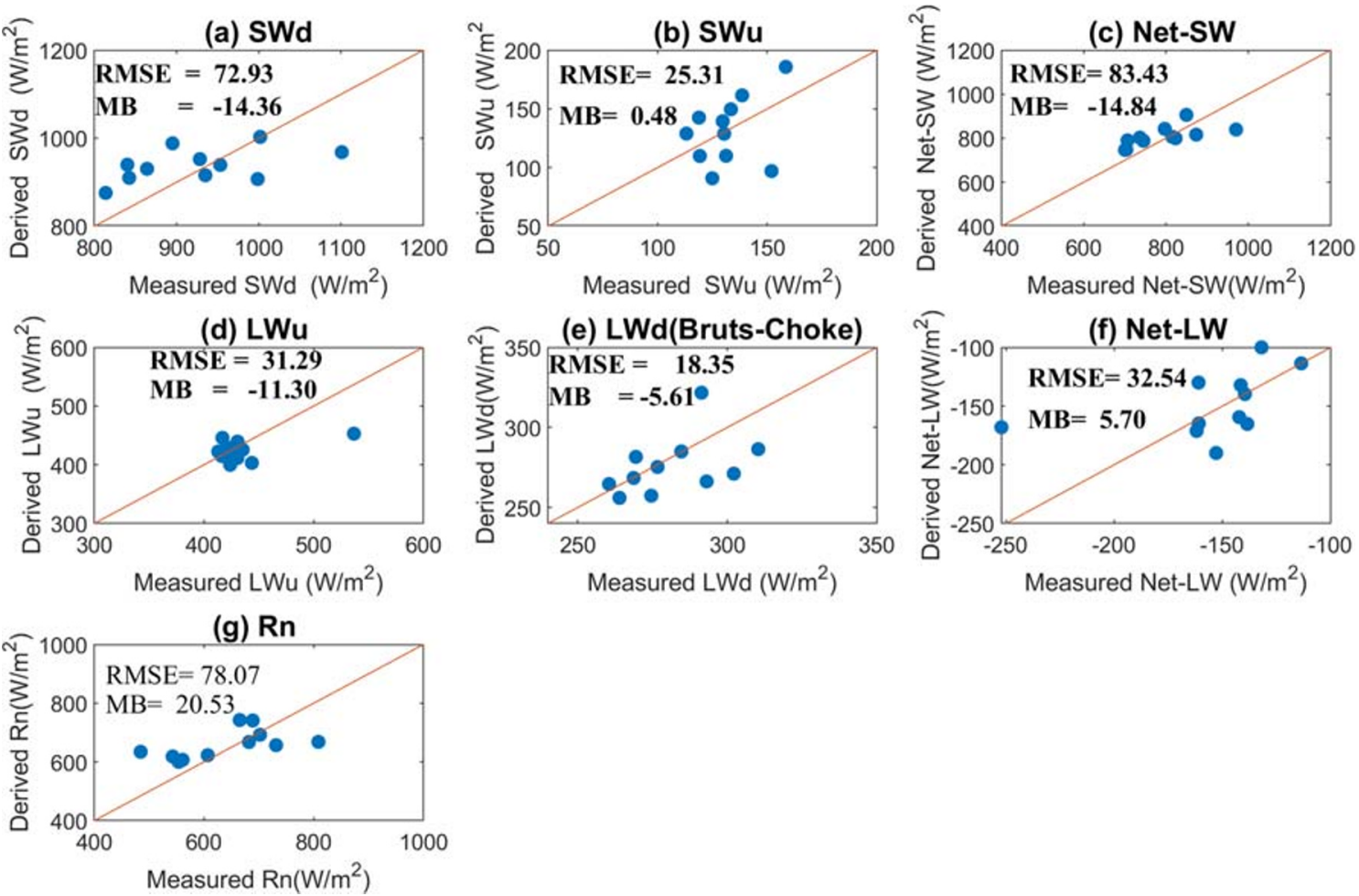

Fig. 4 Comparison of derived results with field measurements for the net radiation flux components: (a) downward shortwave radiation flux (Swd) in $\mathrm{W} \mathrm{m}^{-2}$; (b) shortwave upward radiation flux (SWu) in $\mathrm{W} \mathrm{m}^{-2}$; (c) net shortwave radiation flux (Net-SW) in $\mathrm{W} \mathrm{m}^{-2}$; (d) upward long wave

radiation flux (LWu) in $\mathrm{W} \mathrm{m}^{-2}$; (e) downward long wave radiation flux (LWd) in $\mathrm{W} \mathrm{m}^{-2}$; (f) net long wave radiation flux (Net-LW) in $\mathrm{W} \mathrm{m}^{-2}$; (g) overall net radiation flux $\left(\mathrm{R}_{\mathrm{n}}\right)$ in $\mathrm{W} \mathrm{m} \mathrm{m}^{-2}$ 
alternative techniques for estimation of $L W d$ at specific locations (Iziomon et al. 2003). Most scholars choose to implement the Brutsaert (1975) method to parameterize $L W d$ because it is based on a physically precise approach. Initially, we also chose to follow this method. However, in our study, the original Brutsaert (1975) parameterization scheme underestimated both the net $L W d$ flux and the total net radiation $\left(R_{n}\right)$ when compared with ground truth measurements. This could be attributable to low atmospheric density and highly variable humidity at the high altitude $(4000 \mathrm{~m})$ setting for our eddy covariance measurement station, relative to the lower elevation area for which the Brutsaert (1975) method was initially designed. The Brutsaert (1975) method was found to similarly underestimate fluxes for the Andean Altiplano Plateau, which are at a similar elevation to our study area (Lhomme et al. 2007).

To address this, we adapted the Brutsaert (1975) method to be more appropriate to the atmospheric conditions of our study area. We re-calibrated the method by iteratively adjusting the coefficients and comparing the results to air temperature and vapor pressure measured at the Choke Mountain Flux Tower. The recalibrated model is written as:

$\varepsilon_{a}=1.24\left(2 \frac{e_{a}}{T_{\text {air }}}\right)^{1 / 7} \delta T_{\text {air }}{ }^{4}$

Implementing our recalibrated Brutsaert (1975) method (named the Bruts-Choke method) improved the accuracy of the calculated $L W d$ and net radiation fluxes significantly, as shown in the Table 3.

The original Brutsaert (1975) method is not appropriate for all parts of the world, and several studies have implemented similar recalibrations to ours, for example Culf and Gash (1993) adjusted the method for the dry season in Niger, and Crawford and Duchon (1999) adjusted it for Oklahoma in the USA. In all cases, implementation of the recalibrated Brutsaert (1975) method resulted in a more accurate parameterization than other methods. Sridhar and Elliott (2002) also adapted Brutsaet's original equation by adjusting the coefficient, based on one year of data from different parts of Oklahoma. Our adjustment to the method adapted it be appropriate for the highlands of Ethiopia. However, our recalibration was made using only data from the pre-monsoon season in the central highlands of Ethiopia and we recommend further research to assess the appropriateness of the method over all seasons and for lowland parts of the country.

\subsection{Case study and overall validations}

The UBN River basin covers a vast area and several satellite image tiles were needed to create a composite image of the whole basin. In this study, a mosaic was created from four satellite image tiles each day, and mosaics from eleven days were used for our analysis (Table 2). The downward and upward shortwave and longwave radiative fluxes and the net total radiation were estimated from the satellite data and from the AWS observations made at the satellite overpass time. The estimated radiative fluxes were validated through comparison with ground truth flux measurements made at Choke Mountain $\left(37.84^{\circ} \mathrm{E}, 10.65^{\circ} \mathrm{N}\right)$. The eddy covariance tower at Choke Mountain is the first tower in the UBN River basin to be used for land-atmosphere interaction studies. It was established through a collaboration between then Institute of Tibetan Plateau Research, Chinese Academy of Sciences and the Center for Environmental Sciences, Addis Ababa University and is located in the central part of the basin (Fig. 1b). For the validation, gridded radiative flux estimates from the model were selected to match both the satellite acquisition times and the location of the eddy covariance observation site. These selected model outputs were compared with the tower measurements. The RMSE values for $S W d, S W u, L W d$, and $L W u$ were $72.93,25.31,31.29$, and $18.35 \mathrm{~W} \mathrm{~m}^{-2}$, respectively. The corresponding MB values were, $-14.36,0.48,-11.3$, and $-5.61 \mathrm{~W} \mathrm{~m}^{-2}$, respectively (Fig. 4). Our estimation method successfully retrieved all components of the total radiative flux. The RMSE and MB values for $S W d$ and $S W u$ are lower than those reported in similar studies that have used MODIS data (Gusain et al. 2014; Hwang et al. 2013; Jacobs et al. 2002; Kim 2008; Roupioz et al. 2016). Moreover, RMSE and MB values of $S W u, L W d$, and $R n$ in our results are smaller than the values reported in Chen et al. (2013), which were derived from high-resolution Landsat data using the TESEBS model. However, our validation is based on a single ground truth measurement site in the central part of our study area and may not be representative of the effectiveness of the method for other parts of the study area. For future validation to cover the whole study area, more eddy covariance turbulent measurement systems are required in mid- and low-altitude areas. In the absence of eddy covariance measurements, datasets with fine spatial resolution can be used as complementary data for validation.

The spatial distribution maps of the radiation components ( $S W d, S W u, L W d$, and $L W u$ ) from 10 February 2019, 11:12 am (local time), show the physiographic heterogeneity of the study area (Fig. 5). The eastern, and most central, parts of the basin are at high elevation, where turbidity in the atmosphere is low and the atmospheric attenuation of $S W d$ is small. As a result, the maximum values for $S W d$ occur in these parts of the basin. Rain-fed agriculture is common practice in the highlands of the basin and February is the driest month. With little artificial irrigation over most of the area, vast areas in the basin had an albedo of less than 0.25 for the study period. This is a typical albedo value for soil or dry vegetation. Dry vegetation could include agricultural field residues, left after crop harvesting (Hartmann 2015). The $S W u$ flux was therefore very low and most of the $S W d$ flux may have been converted to a 

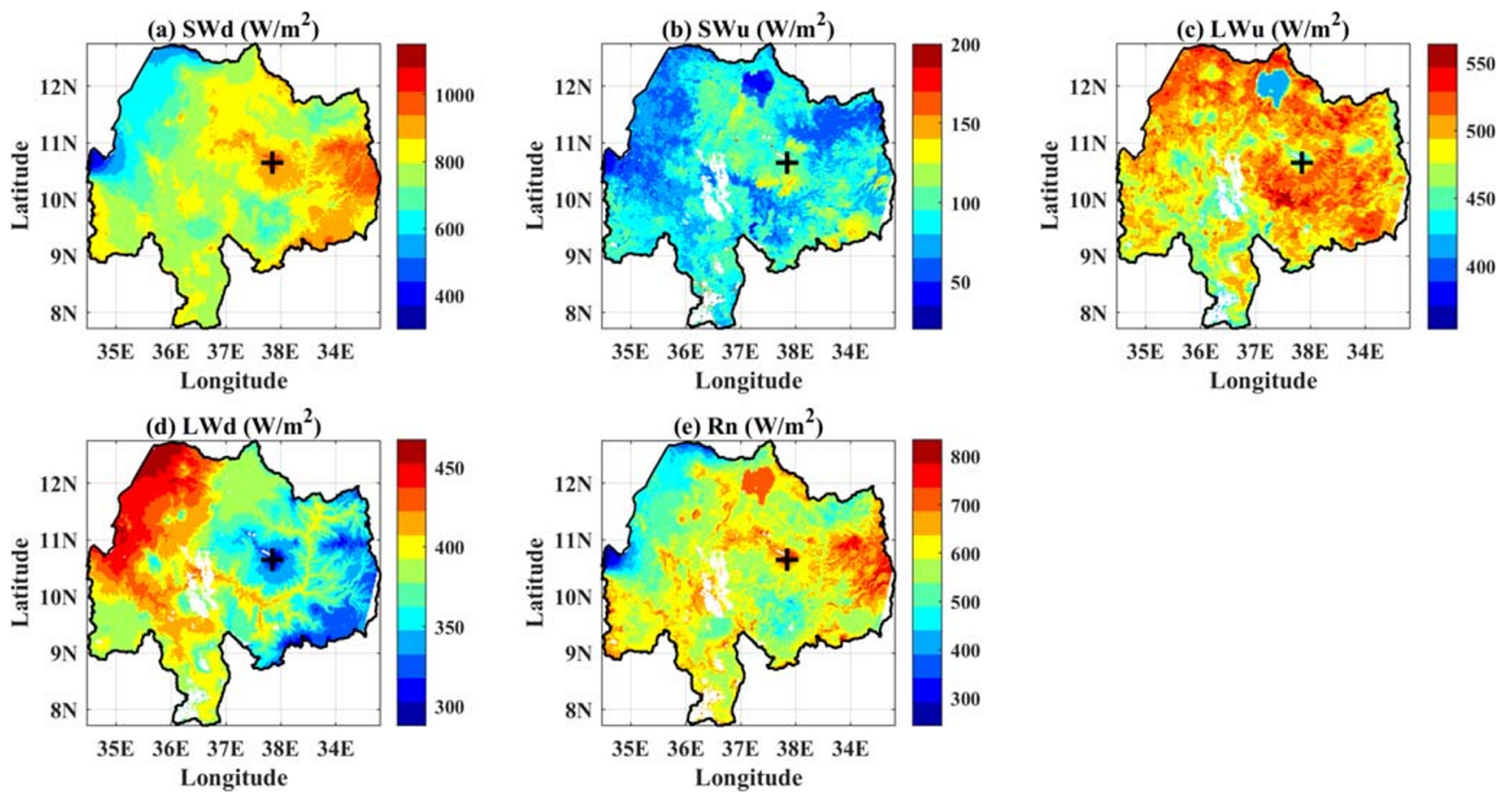

Fig. 5 Spatial distribution maps of components of net radiation flux in $\mathrm{W}$ $\mathrm{m}^{-2}$ over the UBN basin on 10 February 2019, 11:12 am local time: (a) downward shortwave radiation flux (SWd); (b) upward shortwave radiation flux $(\mathrm{SWu}) ;(\mathbf{c})$ upward long wave radiation flux $(\mathrm{LWu}) ;(\mathbf{d})$

downward long wave radiation flux; (e) net radiation flux $\left(\mathrm{R}_{\mathrm{n}}\right)$; location of eddy covariance (EC) tower is designated by $(+)$; white scattered regions represent where no information was available due to cloud cover

soil heat flux and to available energy in the atmosphere (sensible and latent heat fluxes). Looking at parameterizations for soil heat flux and for the available energy flux will be the next focus of our work. Longwave radiation fluxes were strongest over the extensive northwestern lowlands and along the river gorges, which are areas that are warmer than the surrounding plateau. This is because both the upward and downward longwave radiation fluxes depend mainly on the land surface and atmospheric temperature distributions.

Figure $6 \mathrm{a}-\mathrm{d}$ shows the frequency distribution for the net radiation flux at four sample dates within the study period. This study was carried out in the dry season for the basin (February, March, April, and May), when the net radiation flux is large and varies little month to month. This could be related to the clear sky conditions over most parts of the basin since these promote the transfer of large amounts of solar radiation to the surface. The range between the minimum and maximum values for the net radiation flux was large during the study period, which could be due to the heterogeneous landscape and the rugged mountains in the basin. There was also some variability in the shape of the distributions and the spread around the mean. The total net radiation flux ranged from 242.84 to $833.74 \mathrm{~W} \mathrm{~m}^{-2}$ in February, from 40.13 to $867.92 \mathrm{~W} \mathrm{~m}^{-2}$ in March, from 75.63 to $957.75 \mathrm{~W} \mathrm{~m}^{-2}$ in April, and from 150.20 to $738.60 \mathrm{~W} \mathrm{~m}^{-2}$ in May (Table 4 and Fig. 6a-d). The net radiation flux has a negatively skewed distribution for the first three months. The majority of values therefore fall to the right of the mean (to the maximum side) and cluster at the upper end of the distribution, while the tail extends to smaller values.

The main rainy season usually starts in early June in most parts of the UBN River basin, and May is the hottest month before the onset of the major rains (Abera et al. 2016; Conway 200). Our work has shown that basin-wide surface warming in May was more homogeneous and fluxes were more closely concentrated around their mean value than in the preceding months. This can be seen from the smallest standard deviation (Table 4) and leptokurtic frequency distributions (Fig. 6d). This uniform warming could trigger unstable atmospheric conditions, causing air to rise upwards over the study area, promoting cloud formation (Ahrens 2007). However, the upward rising air is unlikely to condense and form precipitation in May as it contains insufficient water vapor. Other studies (Block and Rajagopalan 2007; Gamachu 1977; Griffiths 1972; Mellander et al. 2013) have confirmed that warming

Table 4. Statistical summary of net radiation distributions

\begin{tabular}{lcccc}
\hline Date & Minimum & Maximum & Mean & Standard deviation \\
\hline 10 Feb, 2019 & 242.84 & 833.74 & 587.40 & 26.03 \\
20 March, 2019 & 40.13 & 867.92 & 550.59 & 26.67 \\
26 April, 2019 & 75.63 & 957.75 & 616.02 & 25.69 \\
14 May,2019 & 150.20 & 738.60 & 545.20 & 21.26 \\
\hline
\end{tabular}



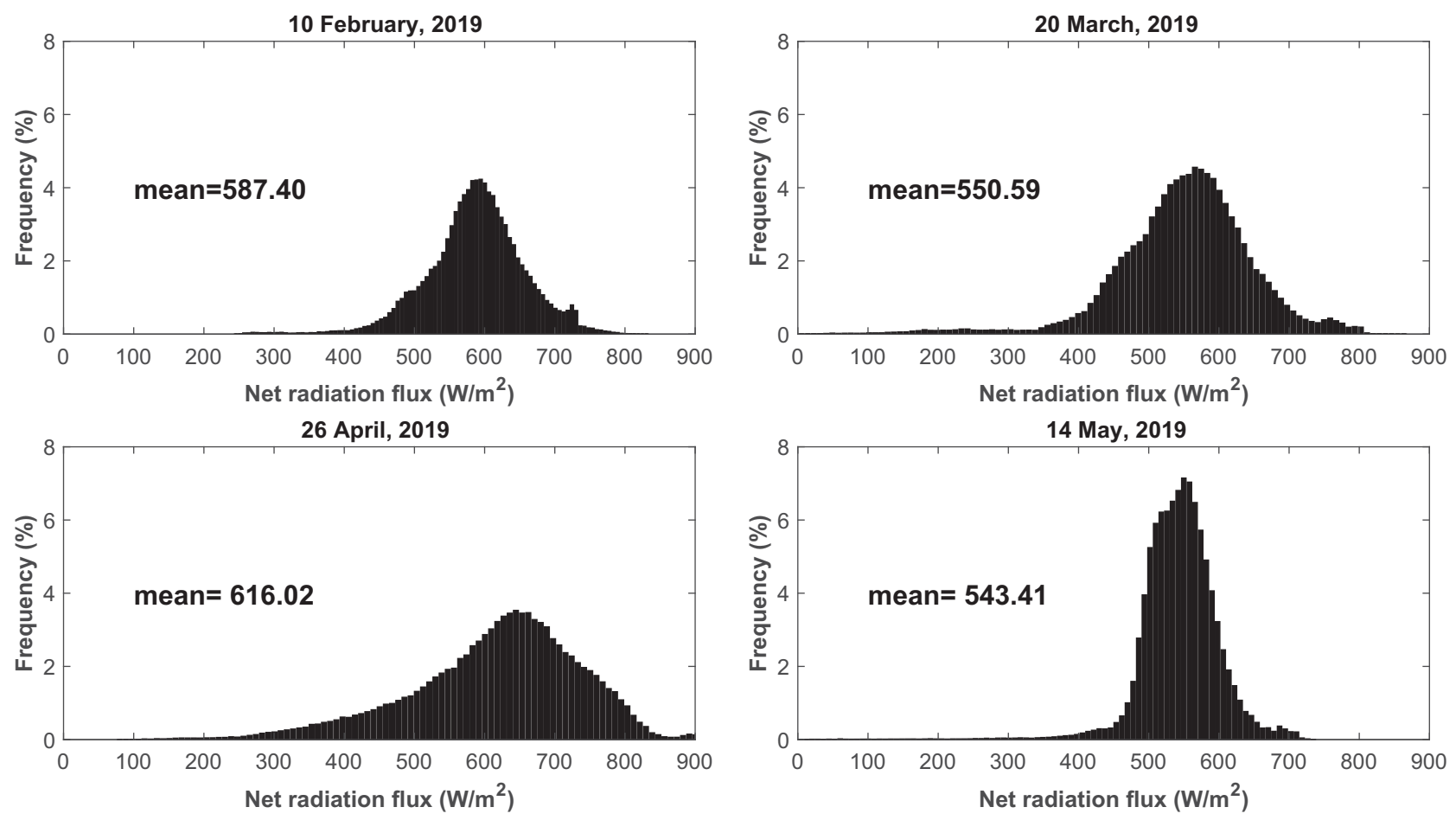

Fig. 6 Frequency distributions of net radiation over the UBN basin area on 10 February, 2019 (a), 20 March, 2019 (b), 26 April, 2019 (c), and 14 May, 2019 (d)

extends north beyond the study area, and moist air from the southwest starts to invade the UBN River basin in June. Previous studies of the main rain-bearing processes in the UBN River basin, however, were carried out in terms of synoptic weather systems (Seleshi and Zanke 2004; Jury 2010 ). The uniform local surface warming and related thermal low conditions in May can be considered a background condition that precedes further warming and the atmospheric processes responsible for the main rain season, which occurs from June to August over most of the UBN River basin.

\section{Conclusions}

In this study, the regional distribution of the component parts of the total net radiation flux (i.e., $S W d, S W u, L W d$, and $L W u$ ) were parameterized over the heterogeneous landscapes of the UBN River basin using DEM, MODIS, and AWS data. The parameterized net radiation flux components were compared with simultaneous, co-located field measurements recorded at the eddy covariance site. The results show that the estimated net radiation flux components are in good agreement with the in situ measurements. The statistical metrics (MB and RMSE) used to characterize the performance of the net radiation parameterization were lower than those reported from similar research carried out using MODIS data in other parts of the world. This is likely to be attributable to the spatial interpolation methods applied in this study, and to the quality of the AWS forcing input data that were used in our estimation processes. The RMSE and MB values for $L W d, S W u$, and $R_{n}$ were smaller than for a similar study that used Landsat data, which have a very fine spatial resolution. This shows that our methodology and study procedures could provide improved and operationally useful results for satellite data with a finer spatial resolution than MODIS.

In this study, the $L W d$ flux parameterization needed to be recalibrated since it was standardized for an environment that was quite different from the atmospheric conditions of our study area. Our recalibrated method drastically improved our estimate of both the $L W d$ flux and the total net radiation flux. The net radiation flux is key to heat exchange and water management studies. Research into Ethiopia in these fields is developing, and the findings of this study provide a springboard to improved understanding of land-atmosphere interactions and will be useful for the science of water resource management, such as ET estimation.

Acknowledgments This research was funded by the Strategic Priority Research Program (A) of the Chinese Academy of Sciences (XDA20060101), the National Natural Science Foundation of China (91837208, 41975009, 41705005), and the Chinese Academy of Sciences (Grant No. QYZDJ-SSW-DQC019). We would like to thank the National Meteorological Agency (NMA), Government of Ethiopia, for providing automatic weather station data. 


\section{Compliance with ethical standards}

Conflict of interests The authors declare that they have no known competing financial interests or personal relationships that could have appeared to influence the work reported in this paper.

Open Access This article is licensed under a Creative Commons Attribution 4.0 International License, which permits use, sharing, adaptation, distribution and reproduction in any medium or format, as long as you give appropriate credit to the original author(s) and the source, provide a link to the Creative Commons licence, and indicate if changes were made. The images or other third party material in this article are included in the article's Creative Commons licence, unless indicated otherwise in a credit line to the material. If material is not included in the article's Creative Commons licence and your intended use is not permitted by statutory regulation or exceeds the permitted use, you will need to obtain permission directly from the copyright holder. To view a copy of this licence, visit http://creativecommons.org/licenses/by/4.0/.

\section{References}

Abera W, Formetta G, Brocca L, Rigon R (2016) Water budget modelling of the Upper Blue Nile basin using the JGrass-NewAge model system and satellite data. Atmos Res:178-179

Abreham A (2009) Open water evaporation estimation using ground measurements and satellite remote sensing: a case study of Lake Tana, Ethiopia. Geo-Inform Earth Observ 26:34-51

Abtew W, Melesse AM, Dessalegne T (2009) Spatial, inter and intraannual variability of the Upper Blue Nile Basin rainfall. Hydrol Process 23(21):3075-3082

Ahmad L, Kanth RH, Parvaze S, Mahdi SS (2017) Experimental agrometeorology: a practical manual. Springer.

Ahrens CD (2007) Meteorology today: an introduction to weather, climate, and the environment /-6th ed[M]. Brooks/Cole

Alemu H, Senay G, Kaptue A, Kovalskyy V (2014) Evapotranspiration variability and its association with vegetation dynamics in the Nile Basin, 2002-2011. Remote Sens 6(7):5885-5908

Alsamamra H, Ruiz-Arias JA, Pozo-Vázquez D, Tovar-Pescador J (2009) A comparative study of ordinary and residual kriging techniques for mapping global solar radiation over southern Spain. Agric For Meteorol 149(8):1343-1357

Amatya PM, Ma Y, Han C, Wang B, Devkota LP (2015a) Estimation of net radiation flux distribution on the southern slopes of the central Himalayas using MODIS data. Atmos Res 154:146-154

Amatya PM, Ma Y, Han C, Wang B, Devkota LP (2015b) Recent trends (2003-2013) of land surface heat fluxes on the southern side of the central Himalayas, Nepal. J Geophys Res-Atmos 120(23):11,95711,970

Amatya PM, Ma Y, Han C, Wang B, Devkota LP (2016) Mapping regional distribution of land surface heat fluxes on the southern side of the central Himalayas using TESEBS. Theor Appl Climatol 124(3): 835-846

Anderson M, Kustas W, Norman J, Hain C, Mecikalski J, Schultz L, González-Dugo M, Cammalleri C, d’Urs G, Pimstein A (2011) Mapping daily evapotranspiration at field to global scales using geostationary and polar orbiting satellite imagery. Hydrol Earth Syst Sci Discuss 7:5957-5990

Beek E (1991) Spatial interpolation of daily meteorological data. Theoretical evaluation of available techniques. Report, 53: 43

Bisht G, Venturini V, Islam S, Jiang L (2005) Estimation of the net radiation using MODIS (Moderate Resolution Imaging
Spectroradiometer) data for clear sky days. Remote Sens Environ 97(1):52-67

Blad B, Walter-Shea E, Mesarch M, Hays C, Starks P, Deering D, Eck T (1998) Estimating net radiation with remotely sensed data: results from KUREX-91 and FIFE studies. Remote Sens Rev 17(1-4):5571

Block P, Rajagopalan B (2007) Interannual variability and ensemble forecast of Upper Blue Nile Basin Kiremt season precipitation. J Hydrometeorol 8(3):327-343

Brutsaert W (1975) On a derivable formula for long-wave radiation from clear skies. Water Resour Res 11(5):742-744

Cai G, Xue Y, Hu Y, Guo J, Wang Y, Qi S (2007) Quantitative study of net radiation from MODIS data in the lower boundary layer in Poyang Lake area of Jiangxi Province, China. Int J Remote Sens 28(19):4381-4389

Carlson TN, Ripley DA (1997) On the relation between NDVI, fractional vegetation cover, and leaf area index. Remote Sens Environ 62(3): $241-252$

Charabi Y, Gastli A (2010) GIS assessment of large CSP plant in Duqum, Oman. Renew Sust Energ Rev 14(2):835-841

Chen X, Su Z, Ma Y, Yang K, Wang B (2013) Estimation of surface energy fluxes under complex terrain of Mt. Qomolangma over the Tibetan Plateau. Hydrol Earth Syst Sci 17(4):1607-1618

Colombi A, De Michele C, Pepe M, Rampini A, Michele CD (2007) Estimation of daily mean air temperature from MODIS LST in Alpine areas. EARSeL eProc 6(1):38-46

Conway D (1997) A water balance model of the Upper Blue Nile in Ethiopia. Hydrol Sci J 42(2):265-286

Conway D (2000) The climate and hydrology of the Upper Blue Nile River. Geogr J 166(1):49-62

Conway D (2005) From headwater tributaries to international river: observing and adapting to climate variability and change in the Nile basin. Glob Environ Chang 15(2):99-114

Crawford TM, Duchon CE (1999) An improved parameterization for estimating effective atmospheric emissivity for use in calculating daytime downwelling longwave radiation. J Appl Meteorol 38(4): 474-480

Cuffey KM, Paterson WSB (2010) The physics of glaciers. 4th ed. San Diego, California Academic Press, pp 704

Culf AD, Gash JH (1993) Longwave radiation from clear skies in Niger: a comparison of observations with simple formulas. J Appl Meteorol 32(3):539-547

Daly C, Gibson WP, Taylor GH, Johnson GL, Pasteris P (2002) A knowledge-based approach to the statistical mapping of climate. Clim Res 22(2):99-113

Dobesch H, Dumolard P, Dyras I (2013) Spatial interpolation for climate data: the use of GIS in climatology and meteorology. ISTE Ltd, London

Dodson R, Marks D (1997) Daily air temperature interpolated at high spatial resolution over a large mountainous region. Clim Res 8(1): $1-20$

Dozier J (1980) A clear-sky spectral solar radiation model for snowcovered mountainous terrain. Water Resour Res 16(4):709-718

Dubayah R (1992) Estimating net solar radiation using Landsat Thematic Mapper and digital elevation data. Water Resour Res 28(9):2469 2484

Duguay C (1995) An approach to the estimation of surface net radiation in mountain areas using remote sensing and digital terrain data. Theor Appl Climatol 52(1-2):55-68

Dryas I, Ustrnul Z (2007) The spatial analysis of the selected meteorological fields in the example of Poland H. Dobesch, et al. (Eds.), Spatial interpolation for climate data: The use of GIS in climatology and meteorology, ISTE Ltd, London, pp 87-96

Eldeiry A, and Garcia L (2009) Comparison of regression kriging and cokriging techniques to estimate soil salinity using landsat images. Hydrology, CO 80523-1372 
Enku T (2009) Estimation of evapotranspiration from satellite remote sensing and meteorological data over the Fogera flood plainEthiopia. ITC, Enschede

ENTRO (2007) Eastern Nile Watershed Management Project. Cooperative regional assessment (CRA) for watershed management. Transboundary analysis. Atlas of Maps, Ethiopia

Estévez J, Gavilán P, Giráldez JV (2011) Guidelines on validation procedures for meteorological data from automatic weather stations. $\mathrm{J}$ Hydrol 402(1-2):144-154

Feng F, Wang K (2017) Merging satellite retrievals and reanalyses to produce global long-term consistent surface solar radiation datasets, AGU Fall Meeting Abstracts.

Flint AL, Childs, SW (1987) The effect of surrounding topography on receipt of solar radiation, Forest hydrology and watershed management, Proceedings of the Vancouver Symposium, pp. 339-347

Flores F, Lillo M (2010) Simple air temperature estimation method from MODIS satellite images on a regional scale. Chilean J Agric Res 70(3):436-445

Gallo K, Hale R, Tarpley D, Yu Y (2011) Evaluation of the relationship between air and land surface temperature under clear- and cloudysky conditions. J Appl Meteorol Climatol 50(3):767-775

Gemechu, D (1977) Aspects of Climate and Water Budget in Ethiopia. Addis Ababa, Addis Ababa University Press, $71 \mathrm{p}$

Gandhi GM, Parthiban S, Thummalu N, Christy A (2015) NDVI: vegetation change detection using remote sensing and GIS - a case study of Vellore District. Proc Comput Sci 57:1199-1210

Gieske A, Rientjes T, Haile AT, Worqlul AW, Asmerom GH (2008) Determination of Lake Tana evaporation by the combined use of SEVIRI, AVHRR and IASI, Proceedings of the 2008 EUMETSAT Meteorological Satellite Conference, Sessioin, p. 7

Glenn EP, Huete AR, Nagler PL, Hirschboeck KK, Brown P (2007) Integrating remote sensing and ground methods to estimate evapotranspiration. Crit Rev Plant Sci 26(3):139-168

Gratton DJ, Howarth PJ, Marceau DJ (1993) Using Landsat-5 thematic mapper and digital elevation data to determine the net radiation field of a mountain glacier. Remote Sens Environ 43(3):315-331

Griffiths J (1972) Ethiopian highlands. World Survey Climatol 10:369388

Gueymard CA (2003a) Direct solar transmittance and irradiance predictions with broadband models. Part I: detailed theoretical performance assessment. Sol Energy 74(5):355-379

Gueymard CA (2003b) Direct solar transmittance and irradiance predictions with broadband models. Part II: validation with high-quality measurements. Sol Energy 74(5):381-395

Gusain H, Mishra V, Arora M (2014) Estimation of net shortwave radiation flux of western Himalayan snow cover during clear sky days using remote sensing and meteorological data. Remote Sens Lett 5(1):83-92

Hachem S, Duguay C, Allard M (2012) Comparison of MODIS-derived land surface temperatures with ground surface and air temperature measurements in continuous permafrost terrain. Cryosphere 6(1): $51-69$

Hadria R, Benabdelouahab T, Mahyou H, Balaghi R, Bydekerke L, El Hairech T, Ceccato P (2018) Relationships between the three components of air temperature and remotely sensed land surface temperature of agricultural areas in Morocco. Int J Remote Sens 39(2):356373

Han C, Ma Y, Liu X, Chen X, Ma W (2013) Estimating land surface energy fluxes over Mt. Everest area of the Tibetan Plateau by using the ASTER and in situ data, EGU General Assembly Conference Abstracts

Han C, Ma Y, Chen X, Su Z (2016) Estimates of land surface heat fluxes of the Mt. Everest region over the Tibetan Plateau utilizing ASTER data. Atmos Res 168:180-190

Hansen MC, Roy DP, Lindquist E, Adusei B, Justice CO, Altstatt A (2008) A method for integrating MODIS and Landsat data for systematic monitoring of forest cover and change in the Congo Basin. Remote Sens Environ 112(5):2495-2513

Hartmann, DL (2015) Global physical climatology, 2nd ed. vol. 103, Elsevier, Amsterdam, pp 425

Hengl T (2009) A practical guide to geostatistical mapping. 2nd ed. University of Amsterdam, Amsterdam, pp 291

Hoch SW, Whiteman CD (2010) Topographic effects on the surface radiation balance in and around Arizona's Meteor Crater. J Appl Meteorol Climatol 49(6):1114-1128

Holdaway MR (1996) Spatial modeling and interpolation of monthly temperature using kriging. Clim Res 6(3):215-225

Hwang K, Choi M, Lee SO, Seo JW (2013) Estimation of instantaneous and daily net radiation from MODIS data under clear sky conditions: a case study in East Asia. Irrig Sci 31(5):1173-1184

Iziomon MG, Mayer H, Matzarakis A (2003) Downward atmospheric longwave irradiance under clear and cloudy skies: measurement and parameterization. J Atmos Sol Terr Phys 65(10):1107-1116

Jacobs JM, Myers DA, Anderson MC, Diak GR (2002) GOES surface insolation to estimate wetlands evapotranspiration. J Hydrol 266(12):53-65

Jia B, Xie Z, Dai A, Shi C, Chen F (2013) Evaluation of satellite and reanalysis products of downward surface solar radiation over East Asia: spatial and seasonal variations. J Geophys Res-Atmos 118(9): 3431-3446

Jin M, Dickinson RE (2010) Land surface skin temperature climatology: benefitting from the strengths of satellite observations. Environ Res Lett 5(4):044004

Jin MS, Mullens TJ (2012) Land-biosphere-atmosphere interactions over the Tibetan plateau from MODIS observations. Environ Res Lett 7(1):014003

Jury MR (2010) Ethiopian decadal climate variability. Theor Appl Climatol 101(1-2):29-40

Jury MR (2011) Climatic factors modulating Nile river flow, in Nile River Basin: Hydrology, Climate and Water Use, edited by A. M. Melesse, pp. 267-280, Springer, Dordrecht, Netherlands

Kim HY (2008) Estimation of land surface radiation budget from MODIS data. Ph.D dissertation, Department of Geography, University of Maryland

Kjærsgaard JH, Cuenca R, Plauborg F, Hansen S (2007) Long-term comparisons of net radiation calculation schemes. Bound-Layer Meteorol 123(3):417-431

Kumar L, Skidmore AK, Knowles E (1997) Modelling topographic variation in solar radiation in a GIS environment. Int J Geogr Inf Sci 11(5):475-497

Kurc SA, Small EE (2004) Dynamics of evapotranspiration in semiarid grassland and shrubland ecosystems during the summer monsoon season, central New Mexico. Water Resour Res 40(9)

Leckner B (1978) The spectral distribution of solar radiation at the earth's surface - elements of a model. Sol Energy 20(2):143-150

Lemann T, Roth V, Zeleke G, Subhatu A, Kassawmar T, Hurni H (2019) Spatial and temporal variability in hydrological responses of the Upper Blue Nile basin, Ethiopia. Water 11(1):21

Lhomme JP, Vacher JJ, Rocheteau A (2007) Estimating downward longwave radiation on the Andean Altiplano. Agric For Meteorol 145(34):139-148 in Environmental sciences: performance and impact factors. Ecological

Li D (2013) Using GIS and Remote Sensing Techniques for Solar Panel Installation Site Selection. M.Sc Thesis, University of Waterloo

Li J, Heap AD (2011) A review of comparative studies of spatial interpolation methods. Informatics 6(3-4):228-241

Liang S (2001) Narrowband to broadband conversions of land surface albedo I: Algorithms. Remote Sens Environ 76(2):213-238

Liao S, Li Z (2004) Some practical problems related to rasterization of air temperature. Meteorol Sci Technol 32(5):352-356 
Liston GE, Elder K (2006) A meteorological distribution system for highresolution terrestrial modeling (MicroMet). J Hydrometeorol 7(2): $217-234$

Liu S, Su H, Zhang R, Tian J, Wang W (2016) Estimating the surface air temperature by remote sensing in Northwest China using an improved advection-energy balance for air temperature model. Advs Meteorol. https://doi.org/10.1155/2016/4294219

Long D, Gao Y, Singh VP (2010) Estimation of daily average net radiation from MODIS data and DEM over the Baiyangdian watershed in North China for clear sky days. J Hydrol 388(3-4):217-233

Marquínez J, Lastra J, García P (2003) Estimation models for precipitation in mountainous regions: the use of GIS and multivariate analysis. J Hydrol 270(1-2):1-11

Martínez-Durbán M, Zarzalejo L, Bosch J, Rosiek S, Polo J, Batlles F (2009) Estimation of global daily irradiation in complex topography zones using digital elevation models and meteosat images: comparison of the results. Energy Convers Manag 50(9):2233-2238

Masuoka E, Fleig A, Wolfe RE, Patt F (1998) Key characteristics of MODIS data products. IEEE Trans Geosci Remote Sens 36(4): $1313-1323$

Medhin G (2011) Livelihood zones analysis: a tool for planning agricultural water management investment. Tech. rep. FAO. http://www. fao.org/publications/card/en/. Accessed 5 Jan 2019

Melesse A, Abtew W, Setegn SG (2014) Nile River basin: ecohydrological challenges, climate change and hydropolitics. Springer International Publishing, Cham. https://doi.org/10.1007/ 978-3-319-02720-3

Mellander PE, Gebrehiwot SG, Gärdenäs AI, Bewket W, Bishop K (2013) Summer rains and dry seasons in the Upper Blue Nile Basin: the predictability of half a century of past and future spatiotemporal patterns. PLoS One 8(7):e68461

Mohamed Y, Van den Hurk B, Savenije H, Bastiaanssen W (2005) Hydroclimatology of the Nile: results from a regional climate model. Hydrol Earth Syst Sci Discuss 2(1):319-364

Molden D, Oweis TY, Pasquale S, Kijne JW, Hanjra MA, Bindraban PS, Bouman BA, Cook, S, Erenstein O, Farahani H (2007) Pathways for increasing agricultural water productivity. D. Molden (Ed.), Water for Food, Water for Life: A Comprehensive Assessment of Water Management in Agriculture, Earthscan/IWMI, London, UK/ Colombo, Sri Lanka, pp 279-310

Monteith JL (1965) Evaporation and environment. The state and movement of water in living organisms, $19^{\text {th }}$ symposium. Society for Experimental Biology, Swansea. Cambridge University Press, Cambridge, pp 205-234

Morillas L, Leuning R, Villagarcía L, García M, Serrano-Ortiz P, Domingo F (2013) Improving evapotranspiration estimates in Mediterranean drylands: the role of soil evaporation. Water Resour Res 49(10):6572-6586

Mukherjee S, Mukherjee S, Garg RD, Bhardwaj A, Raju P (2013) Evaluation of topographic index in relation to terrain roughness and DEM grid spacing. J Earth Syst Sci 122(3):869-886

NBI (2014) Mapping Actual Evapotranspiration over the Nile Basin. Understanding Nile basin hydrology. Nile Basin Initiative Secretariat, Entebbe - Uganda, p 16

Niemelä S, Räisänen P, Savijärvi H (2001) Comparison of surface radiative flux parameterizations: part I: longwave radiation. Atmos Res 58(1):1-18

Ninyerola M, Pons X, Roure JM (2000) A methodological approach of climatological modelling of air temperature and precipitation through GIS techniques. Int J Climatol 20(14):1823-1841

Nishida K, Nemani RR, Running SW, Glassy JM (2003) An operational remote sensing algorithm of land surface evaporation. J Geophys Res-Atmos 108(D9)

Olson M, Rupper S, Shean D (2019) Terrain induced biases in clear-sky shortwave radiation due to digital elevation model resolution for glaciers in complex terrain. Front Earth Sci 7:216
Pebesma EJ (2006) The role of external variables and GIS databases in geostatistical analysis. Trans GIS 10(4):615-632

Peng X, She J, Zhang S, Tan J, Li Y (2019) Evaluation of multi-reanalysis solar radiation products using global surface observations. Atmosphere 10(2):42

Priestley CHB, Taylor R (1972) On the assessment of surface heat flux and evaporation using large-scale parameters. Mon Weather Rev 100(2):81-92

Proy C, Tanre D, Deschamps P (1989) Evaluation of topographic effects in remotely sensed data. Remote Sens Environ 30(1):21-32

Prudhomme C, Reed DW (1999) Mapping extreme rainfall in a mountainous region using geostatistical techniques: a case study in Scotland. Int J Climatol 19(12):1337-1356

Rich PM, Hetrick WA, Saving SC (1995) Modeling topographic influences on solar radiation: a manual for the SOLARFLUX model. Los Alamos National Lab, NM (United States)

Rosenberg NJ, Blad BL, Verma SB (1983) Microclimate: the biological environment. J. Wiley, New York, pp 495

Roth V, Lemann T, Zeleke G, Subhatu AT, Nigussie TK, Hurni H (2018) Effects of climate change on water resources in the upper Blue Nile Basin of Ethiopia. Heliyon 4(9):e00771

Roupioz L, Jia L, Nerry F, Menenti M (2016) Estimation of daily solar radiation budget at kilometer resolution over the Tibetan Plateau by integrating MODIS data products and a DEM. Remote Sens 8(6): 504

Roy DP, Lewis P, Schaaf C, Devadiga S, Boschetti L (2006) The global impact of clouds on the production of MODIS bidirectional reflectance model-based composites for terrestrial monitoring. IEEE Geosci Remote Sens Lett 3(4):452-456

Ryu Y, Kang S, Moon SK, Kim J (2008) Evaluation of land surface radiation balance derived from moderate resolution imaging spectroradiometer (MODIS) over complex terrain and heterogeneous landscape on clear sky days. Agric For Meteorol 148(10): $1538-1552$

Sabatini F (2017) Setting up and managing automatic weather stations for remote sites monitoring: from Niger to Nepal, renewing local planning to face climate change in the tropics. Springer, Cham, pp 21-39

Sardar T, Xu A, Raziq A (2017) Downward shortwave radiation estimation and spatial assessment on sites over complex terrain applying integrative approach of MTCLIM-XL, interpolation, RS and GIS. Environ Syst Decis 37(2):198-213

Schmetz J (1989) Towards a surface radiation climatology: retrieval of downward irradiances from satellites. Atmos Res 23(3-4):287-321

Seleshi Y, Zanke U (2004) Recent changes in rainfall and rainy days in Ethiopia. Int J Climatol 24(8):973-983

Sellers WD (1965) Physical Climatology. Chicago, University of Chicago Press, pp 272

Senay GB, Asante K, Artan G (2009) Water balance dynamics in the Nile Basin. Hydrol Process 23(26):3675-3681

Shanko DL (2015) Use of automated weather stations in Ethiopia, National Meteorological Agency (NMA). Addis Ababa, Ethiopia

Sharan RV (2014) Development of a remote automatic weather station with a pc-based data logger. Int J Hybrid Inform Technol 7(1):233240

Shen S, Leptoukh GG (2011) Estimation of surface air temperature over central and eastern Eurasia from MODIS land surface temperature. Environ Res Lett 6(4):045206

Slater AG (2016) Surface solar radiation in North America: a comparison of observations, reanalyses, satellite, and derived products. J Hydrometeorol 17(1):401-420

Słownik W (1992) International meteorological vocabulary, 1992. WMO/OMM/IMGW, Geneva, p 182

Sluiter, R. (2009). Interpolation methods for climate data: literature review. Intern rapport; IR 2009-04. De Bilt, Royal Netherlands Meteorological Institute (KNMI) pp 28 
Sozzi R, Salcido A, Flores RS, Georgiadis T (1999) Daytime net radiation parameterisation for Mexico City suburban areas. Atmos Res 50(1): $53-68$

Sridhar V, Elliott RL (2002) On the development of a simple downwelling longwave radiation scheme. Agric For Meteorol 112(3-4):237-243

Stephens GL, O'Brien D, Webster PJ, Pilewski P, Kato S, Li J (2015) The albedo of Earth. Rev Geophys 53(1):141-163

Su Z (2002) The Surface Energy Balance System (SEBS) for estimation of turbulent heat fluxes. Hydrol Earth Syst Sci 6(1):85-100

Sun YJ, Wang JF, Zhang RH, Gillies R, Xue Y, Bo YC (2005) Air temperature retrieval from remote sensing data based on thermodynamics. Theor Appl Climatol 80(1):37-48

Sun X, Wilcox BP, Zou CB (2019) Evapotranspiration partitioning in dryland ecosystems: a global meta-analysis of in situ studies. Journal of Hydrology, 576:(123-136)

Tadesse T, Senay GB, Berhan G, Regassa T, Beyene S (2015) Evaluating a satellite-based seasonal evapotranspiration product and identifying its relationship with other satellite-derived products and crop yield: a case study for Ethiopia. Int J Appl Earth Obs Geoinf 40:39-54

Tovar-Pescador J, Pozo-Vázquez D, Ruiz-Arias J, Batlles J, López G, Bosch J (2006) On the use of the digital elevation model to estimate the solar radiation in areas of complex topography. Meteorol Appl 13(3):279-287

Trigo IF, Barroso C, Viterbo P, Freitas SC, Monteiro IT (2010) Estimation of downward long-wave radiation at the surface combining remotely sensed data and NWP data. J Geophys Res-Atmos 115(D24)

Valor E, Caselles V (1996) Mapping land surface emissivity from NDVI: application to European, African, and South American areas. Remote Sens Environ 57(3):167-184

Vancutsem C, Ceccato P, Dinku T, Connor SJ (2010) Evaluation of MODIS land surface temperature data to estimate air temperature in different ecosystems over Africa. Remote Sens Environ 114(2): 449-465

Vico G, Porporato A (2009) Probabilistic description of topographic slope and aspect. J Geophys Res Earth Surf 114(F1)

Wang K, Dickinson RE (2013) Global atmospheric downward longwave radiation at the surface from ground-based observations, satellite retrievals, and reanalyses. Rev Geophys 51(2):150-185

Wang K, Zhou X, Liu J, Sparrow M (2005) Estimating surface solar radiation over complex terrain using moderate-resolution satellite sensor data. Int J Remote Sens 26(1):47-58

Washington R, Harrison M, Conway D, (2004). African Climate Report. Report commissioned by the UK Government to review African climate science, policy and options for action. pp 45. http://www. g7.utoronto.ca/environment/africa-climate.pdf. [Google Scholar]
Wilcox B, Seyfried M, Breshears D, Stewart B, Howell T (2003) The water balance on rangelands. Encyclopedia of Water Sci:791-794

WMO (2007) World guide to the global observing system. $3^{\text {rd }}$ edition WMO-No. 488. World Meteorological Organization, Geneva, pp 170

WMO (2017) Guide to the global observing system. 2010 edition WMONo. 488. World Meteorological Organization, Geneva, pp 228

WMO (2008) Guide to Meteorological Instruments and Methods of Observation. Preliminary seventh edition, WMO-No. 8. World Meteorological Organization, Geneva, pp 681

Wu T, Li Y (2013) Spatial interpolation of temperature in the United States using residual kriging. Appl Geogr 44:112-120

Xiong X, Wenny BN, Barnes WD (2009) Overview of NASA Earth Observing Systems Terra and Aqua moderate resolution imaging spectroradiometer instrument calibration algorithms and on-orbit performance. J Appl Remote Sens 3(1):032501

Yang K, Koike T (2005) A general model to estimate hourly and daily solar radiation for hydrological studies. Water Resour Res 41(10)

Yang K, Huang G, Tamai N (2001) A hybrid model for estimating global solar radiation. Sol Energy 70(1):13-22

Yang K, Koike T, Ye B (2006) Improving estimation of hourly, daily, and monthly solar radiation by importing global data sets. Agric For Meteorol 137(1-2):43-55

Yilma, AD and Awulachew, SB (2009). Characterization and Atlas of the Blue Nile Basins and its sub-basins. International Water Management Institute, Colombo [Google Scholar]

Yilmaz MT, Anderson MC, Zaitchik B, Hain CR, Crow WT, Ozdogan M, Chun JA, Evans J (2014) Comparison of prognostic and diagnostic surface flux modeling approaches over the Nile River basin. Water Resour Res 50(1):386-408

Zeleke T, Giorgi F, Tsidu GM, Diro G (2013) Spatial and temporal variability of summer rainfall over Ethiopia from observations and a regional climate model experiment. Theor Appl Climatol 111(34):665-681

Zeng L, Wardlow B, Tadesse T, Shan J, Hayes M, Li D, Xiang D (2015) Estimation of daily air temperature based on MODIS land surface temperature products over the corn belt in the US. Remote Sens 7(1):951-970

Zhao L, Fu Z, Shen Z, Gao L (2018) Evaluating observation and modeling of net radiation based on remote sensing data and CoLM. Proc. SPIE 10777, Land Surface and Cryosphere Remote Sensing IV, 107770X. https://doi.org/10.1117/12.2324657

Publisher's note Springer Nature remains neutral with regard to jurisdictional claims in published maps and institutional affiliations. 